\title{
QUANTIFICATION OF RESERVE POOL DOPAMINE IN METHIONINE SULFOXIDE REDUCTASE A NULL MICE
}

\author{
Andrea N. Ortiz ${ }^{1}$, Derek B. Oien ${ }^{2,3}$, Jackob Moskovitz², and Michael A. Johnson ${ }^{1,{ }^{*}}$ \\ ${ }^{1}$ Department of Chemistry and R. N. Adams Institute of Bioanalytical Chemistry, Lawrence, KS \\ 66045 USA \\ ${ }^{2}$ Department of Pharmacology \& Toxicology, Lawrence, KS 66045 USA
}

\section{Abstract}

Methionine sulfoxide reductase A knockout $\left(\mathrm{Msr}^{-/-}\right)$mice, which serve as a potential model for neurodegeneration, suffer from increased oxidative stress and have previously been found to have chronically elevated brain dopamine content levels relative to control mice. Additionally, these high levels parallel increased presynaptic dopamine release. In this work, fast-scan cyclic voltammetry at carbon-fiber microelectrodes was used to quantify striatal reserve pool dopamine in knockout mice and wild-type control mice. Reserve pool dopamine efflux, induced by amphetamine, was measured in brain slices from knockout and wild type mice in the presence of a-methyl-p-tyrosine, a dopamine synthesis inhibitor. Additionally, the stimulated release of reserve pool dopamine, mobilized by cocaine, was measured. Both efflux and stimulated release measurements were enhanced in slices from knockout mice, suggesting that these mice have greater reserve pool dopamine stores than wild-type and that these stores are effectively mobilized. Moreover, dopamine transporter labeling data indicate that the difference in measured dopamine efflux was likely not caused by altered dopamine transporter protein expression. Additionally, slices from $\mathrm{MsrA}^{-/}$and wild-type mice were equally responsive to increasing extracellular calcium concentrations, suggesting that potential differences in either calcium entry or intracellular calcium handling are not responsible for increased reserve pool dopamine release. Collectively, these results demonstrate that $\mathrm{Msr}^{-/-}$knockout mice maintain a larger dopamine reserve pool than wild-type control mice, and that this pool is readily mobilized.

\section{Keywords}

methionine sulfoxide reductase; reserve pool; dopamine; voltammetry; cocaine; amphetamine

The abnormal regulation of dopamine (DA) has been associated with multiple neurodegenerative disease states (Bird and Iversen, 1974, Morgan et al., 1987), yet the role of DA reserve pool storage and mobilization in the pathophysiology of these conditions is

\footnotetext{
(C) 2011 IBRO. Published by Elsevier Ltd. All rights reserved.

"Corresponding Author: To whom correspondence should be addressed: Michael A. Johnson, The University of Kansas, Department of Chemistry, 1251 Wescoe Hall Drive, 2010 Malott Hall, Lawrence, KS 66047-7572, Telephone: (785) 864-4629, Fax: (785) 864-4629, johnsonm@ku.edu.

${ }^{3}$ Current address: Boehringer Ingelheim Vetmedica, Inc., Fort Dodge, IA 50501 USA

Section Editor: Cellular, Dr. Menahem Segal, Weizmann Institute of Science, Department of Neurobiology, Hertzl Street, Rehovot 76100, Israel

Publisher's Disclaimer: This is a PDF file of an unedited manuscript that has been accepted for publication. As a service to our customers we are providing this early version of the manuscript. The manuscript will undergo copyediting, typesetting, and review of the resulting proof before it is published in its final citable form. Please note that during the production process errors may be discovered which could affect the content, and all legal disclaimers that apply to the journal pertain.
} 
now just being revealed. Many of these conditions, such as Parkinson's disease, Huntington's disease, and Lou Gehrig's disease, have been associated with the increased production or reactive oxygen species, thereby enhancing the degree of cell oxidative stress in the brain (Patten et al., 2010, Cohen, 1983, Perez-Severiano et al., 2004).

Interestingly, elevated DA levels have also been associated with enhanced oxidative stress (Oien et al., 2008b). Indeed, one model of oxidative stress, methionine sulfoxide reductase A knockout $\left(\mathrm{MsrA}^{--}\right)$mice, have been reported to have chronically high brain DA levels (Oien et al., 2008b). These mice lack the antioxidant enzyme MsrA, which is part of the Msr system. Methionine sulfoxide posttranslational modifications can be reversed by the Msr system, which consists of MsrA (reduces $S$ methionine sulfoxide enantiomer) and MsrB (reduces $R$ methionine sulfoxide enantiomer) (Moskovitz, 2005). The $\mathrm{MsrA}^{-/-}$mouse is hypersensitive to oxidative stress, accumulates higher levels of carbonylated protein, and expresses brain pathologies associated with neurodegenerative diseases (Moskovitz et al., 2001, Pal et al., 2007). Recent studies have shown that these mice have abnormally high DA levels in the brain at the ages of 6 and 12 months, compared to wild type (WT) control mice. Additionally, these high levels parallel an increased presynaptic DA release when stimulated in vitro without drug treatments.

A possible mechanism for an increase in stimulated DA release in $\mathrm{Msr}^{-1-}$ mice involves the mobilization of reserve pool DA. In general, DA-containing vesicles are believed to be separated into three pools: the readily releasable pool (RRP), the recycling pool, and the reserve pool (Neves and Lagnado, 1999, Rizzoli and Betz, 2005). The RRP undergoes exocytosis upon mild stimulation and is replenished by the mobilization of the recycling pool vesicles. The reserve pool, mobilized upon prolonged periods of synaptic activity (Neves and Lagnado, 1999), is the largest pool consisting of 80-90\% of the total vesicles (Rizzoli and Betz, 2005). Pharmacological manipulations, using a combination of alphamethyl-p-tyrosine (aMPT) and either cocaine (COC) or amphetamine (AMPH) (Venton et al., 2006, Ortiz et al., 2010), have been used to quantitatively measure reserve pool dopamine.

Other factors, such as calcium transport, may also influence the amplitude of stimulated dopamine release plots. Transient increases in intracellular calcium concentration trigger vesicular exocytosis (Nachshen and Sanchez-Armass, 1987, Kume-Kick and Rice, 1998) as well as the movement of RRP and reserve pool vesicles (Rose et al., 2002). Moreover, the increase in oxidative stress may result in calcium dysregulation. For example, the activity of calmodulin, a calcium regulatory protein that activates the plasma membrane calcium ATPase (PMCA), diminishes due to oxidative post-translational modifications as tissues age (Michaelis et al., 1996). The oxidation of specific methionines in calmodulin results in about a 50\% reduction of PMCA activation (Bartlett et al., 2003), thereby impairing the ability of cells to clear calcium from the cell (Palacios et al., 2004). Oxidized calmodulin can accumulate in brain tissues as a result of low antioxidant levels and it is speculated that oxidation of methionines on calmodulin may be acting as a molecular switch in calcium regulation, oxidative stress, and DA release (Chen et al., 2001, Bigelow and Squier, 2005).

To investigate possible mechanisms underlying elevated DA content and release found in $\mathrm{MsrA}^{-1-}$ mice, fast-scan cyclic voltammetry (FSCV) at carbon-fiber microelectrodes was used to measure the mobilization and efflux of reserve pool DA in striatal brain slices from $M s r A^{-/-}$mice and WT control mice (Oien et al., 2008b). We hypothesized that the DA reserve pool is enhanced in $\mathrm{MsrA}^{-1-}$ mice compared to WT control mice. In order to measure reserve pool DA, slices were pre-treated with aMPT and then treated with either AMPH, to measure the efflux of reserve pool DA, or with COC, to measure the stimulated release of mobilized DA reserve pool vesicles. Collectively, our results suggest that reserve 
pool DA is more abundant in the $\mathrm{MsrA}^{-/-}$striatum and that the number of vesicles is greater compared to WT controls.

\section{Experimental Procedures}

\section{Animals}

The $\mathrm{Msr}^{-/-}$and WT control mice have been described previously (Moskovitz et al., 2001). All mice used in these experiments were fed ad libitum, housed with $12 \mathrm{~h}$ of light per day, and caged individually. All procedures and conditions of live mice, including euthanasia, were approved by the University of Kansas Institutional Animal Care and Use Committee. Every effort was made to minimize the number of animals used and animal suffering.

\section{Brain Slice Preparation}

Brain slices of 12-month-old $\mathrm{Msr}^{-/-}$mice and age-matched WT control mice were prepared as previously described (Johnson et al., 2006). Brain slices were used as an experimental preparation because they allow for the direct measurement of locally evoked DA release and generally provide higher throughput than whole animal preparations. Mice were anesthetized by isoflurane inhalation and then decapitated. The brain was immediately removed and placed in ice cold artificial cerebrospinal fluid (aCSF) consisting of (mM): $\mathrm{NaCl} 126, \mathrm{KCl} 2.5, \mathrm{NaH}_{2} \mathrm{PO}_{4} 1.2, \mathrm{CaCl}_{2} 2.4, \mathrm{MgCl}_{2} 1.2, \mathrm{NaHCO}_{3} 25$, HEPES 20, and DGlucose 11. The $\mathrm{pH}$ of the aCSF was adjusted to 7.4. The cerebellum was removed from the brain using a razor blade and the brain was then mounted on an aluminum block. A vibratome slicer (Leica, Wetzlar, Germany) was used to make $300 \mu \mathrm{m}$ thick coronal slices. Each brain slice was equilibrated in the superfusion chamber which was maintained at $34^{\circ} \mathrm{C}$, through which aCSF flowed at a continuous rate of $2 \mathrm{~mL} / \mathrm{min}$, prior to obtaining measurements.

\section{DA Release in Brain Slices}

Carbon-fiber microelectrodes were fabricated using a single $7 \mu \mathrm{m}$ diameter carbon-fiber (Goodfellow Cambridge Ltd, Huntingdon, U.K.) that was aspirated through a glass capillary tube (1.2 $\mathrm{mm}$ outer diameter, $0.68 \mathrm{~mm}$ inner diameter, $20 \mathrm{~mm}$ long, A-M Systems, Inc. Carlsborg, WA), and was pulled using a heated coil puller (Narishige International USA, Inc., East Meadow, NY) (Kraft et al., 2009). The carbon-fiber was trimmed to about $25 \mu \mathrm{M}$ and further insulated using with epoxy resin (EPON resin 815C, EPIKURE 3234 curing agent, Miller-Stephenson, Danbury, CT, USA), and then cured at $100^{\circ} \mathrm{C}$ for $1 \mathrm{~h}$. The electrodes were backfilled with $0.5 \mathrm{M}$ potassium acetate to provide an electrical connection between the carbon fiber and an inserted silver wire.

A triangular waveform was applied to the carbon-fiber electrode starting at $-0.4 \mathrm{~V}$, increasing to $+1.0 \mathrm{~V}$, and then scanning back down to $-0.4 \mathrm{~V}$. For stimulated release measurements, a scan rate of $300 \mathrm{~V} / \mathrm{s}$ and an update rate of 60 cyclic voltammograms (CVs) per second were used. For measurements of AMPH-induced DA efflux, an update rate of 5 CVs was used to limit the memory space occupied by the file. A headstage amplifier (UNC Chemistry Department Electronics Design Facility, Chapel Hill, NC) was interfaced with a computer via a breakout box and custom software provided by R.M. Wightman and M.L.A.V. Heien (University of North Carolina, Chapel Hill). A Ag/AgCl reference electrode consisted of a chorided silver wire. The carbon fiber microelectrode was inserted $100 \mu \mathrm{m}$ into the dorsolateral caudate-putamen region of the striatum between the prongs of a bipolar stimulation electrode (Plastics One, Roanoke, VA), which was separated by a distance of $200 \mu \mathrm{m}$. A single pulse at $60 \mathrm{~Hz}$ was applied to the brain slice and the current was then measured at the peak oxidation potential for DA (about $+0.6 \mathrm{~V}$ versus $\mathrm{Ag} / \mathrm{AgCl}$ reference electrode). Working electrodes were calibrated with DA standards of known 
concentration in a flow cell before and after each use. The average of pre- and postcalibration measurements was used as the calibration factor. Drugs were introduced into the brain slice superfusion chamber by opening a three-way valve that allowed the desired solution to flow by gravity feed.

For AMPH-induced DA efflux experiments, brain slices were stimulated with single electrical stimulus pulses until the magnitude of evoked DA release was consistent between measurements. Brain slices were then treated with $50 \mu \mathrm{M}$ aMPT. During this treatment, stimulated DA release was measured every $5 \mathrm{~min}$. Once DA release diminished, $20 \mu \mathrm{M}$ AMPH was added to the aCSF/aMPT solution and a 25 min duration file was collected.

To measure electrically evoked DA release from mobilized reserve pool vesicles, the same procedure for pre-treatment with aMPT was used. However, slices were treated with $20 \mu \mathrm{M}$ COC after stimulated release was diminished. During this treatment, electrically-evoked release was measured every 5 minutes.

\section{Sensitivity of DA release to extracellular calcium}

To measure changes in the sensitivity to calcium in $\mathrm{MsrA}^{-/}$mice DA release evoked by a single electrical stimulus pulse was first measured in slices with aCSF that contained 2.4 $\mathrm{mM}$ calcium. Next, aCSF containing $0 \mathrm{mM}$ calcium was introduced into the superfusion chamber. Once DA release disappeared, brain slices were cumulatively treated with aCSF containing $0.6,1.2,1.8$, and $2.4 \mathrm{mM}$ calcium. Slices were treated with each concentration for $15 \mathrm{~min}$, with files collected every five $5 \mathrm{~min}$ using a single pulse stimulation. Values obtained at the 15 min point were used in Fig. 4.

\section{Immunoblotting}

$M s r A^{-/-}$and WT brains were dissected from post-mortem mice. Each striatal lysate was placed in a glass tube and homogenized with Teflon in $50 \mathrm{mM}$ HEPES buffer $\mathrm{pH} 7.4$ plus protease inhibitors (Roche) at $4^{\circ} \mathrm{C}$. Homogenized extract was centrifuged for $20 \mathrm{~min}$ to separate the membrane fraction. Buffer containing $50 \mathrm{mM}$ HEPES, 0.62\% CHAPS, and 150 $\mathrm{mM} \mathrm{NaCl}$ was added to each membrane fraction and agitated for $30 \mathrm{~min}$. Each fraction was centrifuged for $20 \mathrm{~min}$. Protein concentration of the supernatant was determined by BCA Protein Assay Kit (Pierce). Equal protein amounts $(20 \mu \mathrm{g})$ of each soluble membrane fraction was loaded into a HEPES 4-20\% Protein Gel (Pierce, Pittsburg, PA) for electrophoretic separation. Proteins were transferred to a nitrocellulose membrane and blocked overnight in 5\% dry milk in buffer. DAT band was detected using primary rabbit anti-DAT antibodies (1:1000; Chemicon, Billerica, MA). Peroxide-conjugated goat-antirabbit antibodies were used as secondary antibodies (1:2000; Bio-Rad, Hercules, CA). Protein bands were visualized by chemiluminescent substrate and exposure to autoradiography film. Densitometry analysis was done using ImageJ software (publicly available software obtained from the National Institutes of Health website).

\section{Statistical Analyses}

Data were analyzed by ANOVA or students t-test using GraphPad Prism 4.03 (GraphPad Software, Inc., La Jolla, CA). All numerical values are represented as mean \pm SEM. A $p$ value of 0.05 or less was considered significant.

\section{Results}

\section{Reserve Pool DA Levels}

It has been previously demonstrated that in $\mathrm{Msr}^{-/-}$mice stimulated DA release, evoked by a single-pulse electrical stimulation, is significantly higher than that of WT controls (Oien et 
al., 2008b). To determine if reserve pool DA is similarly more abundant in $M s r A^{-/}$mice, striatal brain slices were subjected to treatment with aMPT and AMPH-induced efflux was measured. Each slice was treated with $50 \mu \mathrm{M}$ aMPT to inhibit tyrosine hydroxylase, the rate limiting enzyme in DA synthesis. A stimulus pulse was then applied to the slice every 5 min until DA release was diminished. At this point, DA remaining in terminals consisted only of reserve pool DA. The slices were then treated with $20 \mu \mathrm{M}$ AMPH, a competitive DAT inhibitor that induces the quantitative efflux of cytosolic and vesicular DA. AMPH enters the pre-synaptic terminals in one of two ways: either by lipophilic diffusion through membranes or by passage through DAT protein molecules (Fischer and Cho, 1979, Liang and Rutledge, 1982). AMPH displaces vesicular DA into the cytoplasm and induces DA reverse transport, caused by allosteric translocation of the DAT protein molecules (Chiueh and Moore, 1975, Jones et al., 1998). The AMPH induced efflux of DA was measured over the course of 25 min and the amplitude of the DA peak ([DA $]_{\mathrm{AMPH}}$ ) was used to determine the amount of DA released (Fig.1a). A CV, which has an oxidation peak at $\sim 0.6 \mathrm{~V}$ and a reduction peak at $\sim-0.2 \mathrm{~V}$, shown at the peak current on this efflux curve indicates that the species released by AMPH treatment is DA. In $\mathrm{MsrA}^{-/}$mice, AMPH-induced DA efflux was significantly greater than that observed in WT control mice, indicating that the striatal DA reserve pool is enhanced in $\mathrm{Msr}^{-/} \mathrm{A}^{-}$mice (Fig. $1 \mathrm{~b} ; p=0.022 ; \mathrm{Msr}^{-/}, 7.02 \pm 1.42 \mu \mathrm{M}$, $\mathrm{n}=5$ mice; WT, $5.63 \pm 0.33 \mu \mathrm{M}, \mathrm{n}=4$ mice).

\section{Mobilization of Reserve Pool DA}

To identify differences in the exocytotic release of mobilized DA reserve pool vesicles, DA release, electrically evoked in striatal brain slices from $\mathrm{MsrA}^{-1-}$ and WT mice control mice, was measured with FSCV (Fig. 2a). Once DA release peak amplitude was the same between separate stimulations in the absence of drug, aMPT was added to the perfusate at a final concentration of $50 \mu \mathrm{M}$ in order to stop DA synthesis. After DA release was diminished, COC was added to the aMPT/aCSF solution at a final concentration of $20 \mu \mathrm{M}$. COC has previously been shown to mobilize reserve pool DA (Venton et al., 2006). DA release was electrically evoked by the application of locally applied single stimulus pulses every $5 \mathrm{~min}$ throughout the entire process. The addition of COC caused stimulated DA release to grow in both $M s r A^{-1-}$ and WT control slices. Although COC treatment caused DA release to increase to similar levels in $M s r A^{-/-}$and WT control slices, DA release reappeared for a longer amount of time in slices from $\mathrm{Msr}^{-/-}$mice ( $\left.180 \mathrm{~min}\right)$ compared to slices from WT mice ( $\sim 80 \mathrm{~min})$ (Fig. $2 \mathrm{~b}$ ). The area under the curve generated using slices from WT mice was $40 \%$ of that generated using slices from $\mathrm{MsrA}^{-1-}$ mice.

\section{DAT Protein Levels}

The DAT is a transmembrane protein that moves DA from the synaptic cleft into the presynaptic neuron. In membrane fractions of $\mathrm{MsrA}^{-/}$and WT mice, no difference in DAT protein levels was detected (Fig. 3; $p=0.65 ; \mathrm{Msr}^{-/}, 115.6 \pm 4.1 \%, \mathrm{n}=3$ mice; WT, $100.0 \pm 19.8 \%, \mathrm{n}=3$ mice). These data are consistent with a previous report that showed synaptic DA clearance was similar between $\mathrm{MsrA}^{-/-}$and WT mice (Oien et al., 2008).

\section{Extracellular Calcium Sensitivity}

Vesicular DA exocytosis in the striatum is directly dependent on available extracellular calcium, which enters pre-synaptic terminals by voltage-gated calcium channels during membrane depolarization (Heuser and Reese, 1973; Cremona and De Camilli, 1997). In order to evaluate whether the calcium dependency of release was altered in $\mathrm{Msr}^{-/}$- mice, brain slices were treated with various concentrations of extracellular calcium and stimulated DA release was measured (Fig. 4). All peak DA release values were normalized against peak DA release obtained at $2.4 \mathrm{mM} \mathrm{Ca}^{2+}$, which is the concentration of $\mathrm{Ca}^{2+}$ present in the aCSF that was used for measuring the total amount of DA present in the reserve pool (Figs 1 
and 2). The purpose of this normalization was to minimize variation caused by heterogeneity in dopaminergic innervation found in the striatum. A two-way ANOVA did not reveal an overall genotype effect on DA release throughout the entire range of extracellular calcium concentrations (Fig. $4 ; p=0.97 ; \mathrm{F}_{1,44}=0.00 ; \mathrm{MsrA}^{-/-}, \mathrm{n}=4$ to 6 mice; WT, $\mathrm{n}=6$ mice).

\section{Discussion}

Previous studies using $\mathrm{Msr}^{-/-}$mice have shown that DA release evoked using a singlepulse stimulation is increased (Oien et al., 2008b). In the present study, differences in DA reserve pool storage and mobilization in striatal brain slices from $\mathrm{MsrA}^{-/}$mice and WT control mice were examined. AMPH-induced DA efflux, following pre-treatment with aMPT, was increased in striatal brain slices from $\mathrm{MsrA}^{-/}$mice compared to those of WT littermates. Moreover, $\mathrm{Msr}^{-/}$slices showed an enhanced degree of COC-induced mobilization of DA reserve pool vesicles compared to WT. Furthermore, slices from $\mathrm{MsrA}^{-1-}$ mice and WT control mice were equally sensitive to changes in extracellular calcium concentration.

Initial experiments were aimed at determining if alterations in either DAT or calcium regulation preferentially enhanced DA release in $\mathrm{MsrA}^{-/-}$mice. Our previous work has shown that the efficiency of DA reuptake by DAT is similar in $M s r A^{-/}$and WT mice (Oien et al., 2008b). Furthermore, here we show that DAT protein levels are similar in $\mathrm{Msr}^{-/-}$ and WT mice. This result further supports the concept that DAT function and protein levels are not altered in the absence of MsrA. Therefore, we expect that COC and AMPH effects on the DAT would be similar in both mice genotypes.

The exocytotic release of DA during synaptic transmission is mediated by calciumdependent fusion with the active zone (Heuser and Reese, 1973; Cremona and De Camilli, 1997; Kavalali, 2006). Thus, the ability of extracellular calcium to enter through N- and P/ Q-type voltage-gated calcium channels (VGCCs) located at the active zone exerts a strong influence over neurotransmitter release (Fox and Currie, 1997). We observed no difference in electrically evoked DA release between $\mathrm{MsrA}^{-/-}$and WT slices when extracellular calcium concentrations were increased, suggesting that the VGCCs were functioning similarly. However, it is important to note that this experiment, due to its limited scope, cannot rule out potential alterations in other calcium handing mechanisms in $\mathrm{Msr}^{-/-}$mice, and the possibility that such alterations may somehow influence the ability of terminals to release DA, especially since intracellular calcium can influence the movement of vesicular DA between RRP and reserve pools (Rose et al., 2002).

One potential mechanism that could increase intracellular calcium levels, although not supported by the data presented in this report, is the oxidative inactivation of calcium regulatory proteins. In particular, methionine oxidation of calcium regulatory proteins, such as calmodulin (Michaelis et al., 1996) and calcium/calmodulin kinase II (Erickson et al., 2008), increases with age and is also increased in selenium deficient $\mathrm{Msr}^{-/-}$mice compared to WT control mice (Moskovitz, 2007). Data obtained using patch clamp methods in several cell types (Zucker and Regehr, 2002), including studies conducted using dopaminergic retinal amacrine cells (Borges et al., 1995) and retinal bipolar cells (Gomis et al., 1999), suggest that the translocation of reserve pool vesicles are influenced by changes in intracellular $\mathrm{Ca}^{2+}$ levels. Thus, it seems plausible that fluctuations in intracellular $\mathrm{Ca}^{2+}$ levels associated with a lack of calcium chelating ability would influence reserve pool DA mobilization in $\mathrm{MsrA}^{-/}$mice.

To assess the content and mobilization of reserve pool DA in $\mathrm{MsrA}^{-/}$and WT control mice, selected pharmacological agents were used. Treating brain slices with aMPT while 
electrically stimulating the brain slice depletes DA in RRP vesicles. Under these conditions, DA in the extracellular space will be packaged and also released, leaving only DA in reserve pool vesicles (Ortiz et al., 2010). Upon the addition of AMPH, DA in the reverse pool vesicles is released by reverse transport through the DAT and we are able to measure the resulting efflux. We found that, compared with WT littermate controls, AMPH-induced DA efflux is greater in $\mathrm{Msr}^{-/-}$slices compared to WT slices, indicating that $\mathrm{MsrA}^{-/-}$mice have an increased supply of reserve pool dopamine. This increase parallels both the enhancement of stimulated DA release and the increase in striatal DA content found previously in $\mathrm{Msr}^{-/-}$mice (Oien et al., 2008b). Because it appears that similar equal levels of the DAT protein are found in $\mathrm{Msr}^{-/-}$and WT mice, and DA uptake in the absence of pharmacological treatments appears to be similar between the two strains, it is unlikely that the enhancement of DA efflux found in the $\mathrm{Msr}^{-/}$striatum is the result of alterations in DAT expression or function. Thus, our results suggest that the overall amount of reserve pool DA is increased in the $M r s A^{-/}$striatum.

When DA reserve pool vesicles are mobilized by the application of COC, peak DA release evoked by single-pulse stimulation was the same between the $\mathrm{MsrA}^{-/-}$and WT mice, implying that there are the same number of DA molecules contained in each mobilized reserve pool vesicle. Because the peak dopamine release is attained earlier in WT mice than in $\mathrm{MsrA}^{-/-}$mice, impaired mobilization of reserve pool vesicles in the $\mathrm{MsrA}^{-/-}$cannot be ruled out. The area under the curve generated from WT slices was about $40 \%$ of the area under the curve generated from $M s r A^{-/}$slices. Because the peak amounts of DA released by WT and $\mathrm{MsrA}^{-/-}$slices following cocaine treatment were unchanged, we speculate that the genotypes have similar amounts of DA packaged in the vesicles. If this is indeed the case, then the area under the curve calculations would suggest that the WT striatum possesses $40 \%$ the number of DA reserve pool vesicles found in the $\mathrm{MsrA}^{-/}$striatum. This figure is in close agreement with the amount of DA released by electrical stimulation in the WT striatum (37\% of $\mathrm{MsrA}^{-1}$; Oien et al., 2008b). Thus, it may be that a greater overall number of vesicles, albeit a similar proportion in relation to the reserve pool, are mobilized into the RRP in $\mathrm{MsrA}^{-/}$mice than in WT mice. These vesicles then undergo exocytosis upon the application of a mild electrical stimulus pulse, which is intended to simulate the occurrence of a natural action potential. We speculate that this increase in the number of reserve pool vesicles enhances the magnitude of naturally occurring DA release events in $M s r A^{-1-}$ mice.

The mechanism of the chronically increased DA levels in $\mathrm{MsrA}^{-/-}$mice is still unknown. The abnormally high brain DA in $\mathrm{MsrA}^{-/}$mice can be alleviated by caloric restriction (Oien et al., 2010), suggesting that metabolism and oxidative stress related mechanisms are involved in this phenomenon. Previous studies suggest an increase of the tyrosine hydroxylase activating protein 14-3-3zeta mRNA (Oien et al., 2008a) and protein (Oien et al., 2008b) may be associated with the increased levels of DA by enhanced DA synthesis. In addition, we have recently reported that methionine oxidation of the dopamine $\mathrm{D} 2$ receptor may participate in DA signaling in $M s r A^{-/}$mice (Oien et al., 2010), which may include the presynaptic D2 autoreceptor isoform. Another possible explanation for this abnormal DA regulation is increased methionine sulfoxide levels in alpha-synuclein that may interfere with its interaction with DA (Oien and Moskovitz, 2008, Oien et al., 2009, Outeiro et al., 2009). This theory is further supported by defective mobilization of DA from reserve pools in alpha-synuclein knockout mice and A30P mutated alpha-synuclein transgenic mice (Yavich et al., 2004, Yavich et al., 2005). In any case, it is apparent that dopaminergic neurons store this excess DA in reserve pool vesicles.

In summary, this work indicates that $\mathrm{Msr}^{-/-}$mice have an increase amount of DA stored in the striatal reserve pool compared to WT control mice. To our knowledge, this is the first 
published study in which reserve pool DA levels have been directly measured in mice that are genetically altered to have increased oxidative stress. Moreover, this study offers a potential mechanism by which neurons cope with the excessive production of DA, and also provides a strategy for the study other DA-related pathologies.

\section{Acknowledgments}

This study was supported by funding from NIH P20 RR016475 from the INBRE Program of the National Center for Research Resources, Huntington's disease Society of America, the KIDDRC HD02528 Center grant, the National Institute of Aging AG027363 grant, the KU School of Pharmacy General Research Fund, and the University of Kansas. We would like to thank Renea D. Creech for her technical assistance.

\section{List of Abbreviations}

$\begin{array}{ll}\text { DA } & \text { dopamine } \\ \text { MsrA }^{-/-} & \text {methionine sulfoxide reductase A knockout } \\ \text { FSCV } & \text { fast-scan cyclic voltammetry } \\ \text { aMPT } & \text { alpha-methyl-p-tyrosine } \\ \text { AMPH } & \text { amphetamine } \\ \text { COC } & \text { cocaine } \\ \text { WT } & \text { wild type } \\ \text { aCSF } & \text { artificial cerebral spinal fluid } \\ \text { RRP } & \text { readily releasable pool } \\ \text { DAT } & \text { dopamine transporter }\end{array}$

\section{References}

Bartlett RK, Bieber Urbauer RJ, Anbanandam A, Smallwood HS, Urbauer JL, Squier TC. Oxidation of Met144 and Met145 in calmodulin blocks calmodulin dependent activation of the plasma membrane Ca-ATPase. Biochemistry. 2003; 42:3231-3238. [PubMed: 12641454]

Bigelow DJ, Squier TC. Redox modulation of cellular signaling and metabolism through reversible oxidation of methionine sensors in calcium regulatory proteins. Biochim Biophys Acta. 2005; 1703:121-134. [PubMed: 15680220]

Bird ED, Iversen LL. Huntington's chorea. Post-mortem measurement of glutamic acid decarboxylase, choline acetyltransferase and dopamine in basal ganglia. Brain. 1974; 97:457-472. [PubMed: 4157009]

Borges S, Gleason E, Turelli M, Wilson M. The Kinetics of Quantal Transmitter Release from Retinal Amacrine Cells. Proc Nat Acad Sci USA. 1995; 92:6896-6900. [PubMed: 7624339]

Chen BT, Avshalumov MV, Rice ME. H(2)O(2) is a novel, endogenous modulator of synaptic dopamine release. J Neurophysiol. 2001; 85:2468-2476. [PubMed: 11387393]

Chiueh CC, Moore KE. D-amphetamine-induced release of "newly synthesized" and "stored" dopamine from the caudate nucleus in vivo. J Pharmacol Exp Ther. 1975; 192:642-653. [PubMed: 1120962]

Cohen G. The pathobiology of Parkinson's disease: biochemical aspects of dopamine neuron senescence. J Neural Transm Suppl. 1983; 19:89-103. [PubMed: 6321651]

Erickson JR, Joiner ML, Guan X, Kutschke W, Yang J, Oddis CV, Bartlett RK, Lowe JS, O'Donnell SE, Aykin-Burns N, Zimmerman MC, Zimmerman K, Ham AJ, Weiss RM, Spitz DR, Shea MA, Colbran RJ, Mohler PJ, Anderson ME. A dynamic pathway for calcium-independent activation of CaMKII by methionine oxidation. Cell. 2008; 133:462-474. [PubMed: 18455987] 
Fischer JF, Cho AK. Chemical release of dopamine from striatal homogenates: evidence for an exchange diffusion model. J Pharmacol Exp Ther. 1979; 208:203-209. [PubMed: 762652]

Fox AP, Currie KPM. Comparison of N- and P/Q-Type Voltage-Gated Calcium Channel Current Inhibition. J Neurosci. 1997; 17:4570-4579. [PubMed: 9169518]

Gomis A, Burrone B, Lagnado L. Two actions of calcium regulate the supply of releasable vesicles at the ribbon synapse of retinal bipolar cells. J Neurosci. 1999; 19:6309-6317. [PubMed: 10414960]

Johnson MA, Rajan V, Miller CE, Wightman RM. Dopamine release is severely compromised in the R6/2 mouse model of Huntington's disease. J Neurochem. 2006; 97:737-746. [PubMed: 16573654]

Jones SR, Gainetdinov RR, Wightman RM, Caron MG. Mechanisms of amphetamine action revealed in mice lacking the dopamine transporter. J Neurosci. 1998; 18:1979-1986. [PubMed: 9482784]

Kline DD, Takacs KN, Ficker E, Kunze DL. Dopamine Modulates Synaptic Transmission in the Nucleus of the Solitary Tract. J Neurophysiol. 2002; 88:2736-2744. [PubMed: 12424308]

Kraft JC, Osterhaus GL, Ortiz AN, Garris PA, Johnson MA. In vivo dopamine release and uptake impairments in rats treated with 3-nitropropionic acid. Neuroscience. 2009; 161:940-949. [PubMed: 19362126]

Kume-Kick J, Rice ME. Dependence of dopamine calibration factors on media $\mathrm{Ca} 2+$ and $\mathrm{Mg} 2+$ at carbon-fiber microelectrodes used with fast-scan cyclic voltammetry. J Neurosci Methods. 1998; 84:55-62. [PubMed: 9821634]

Liang NY, Rutledge CO. Evidence for carrier-mediated efflux of dopamine from corpus striatum. Biochem Pharmacol. 1982; 31:2479-2484. [PubMed: 7126258]

Michaelis ML, Bigelow DJ, Schoneich C, Williams TD, Ramonda L, Yin D, Huhmer AF, Yao Y, Gao J, Squier TC. Decreased plasma membrane calcium transport activity in aging brain. Life Sci. 1996; 59:405-412. [PubMed: 8761328]

Morgan DG, May PC, Finch CE. Dopamine and serotonin systems in human and rodent brain: effects of age and neurodegenerative disease. J Am Geriatr Soc. 1987; 35:334-345. [PubMed: 3549845]

Moskovitz J. Methionine sulfoxide reductases: ubiquitous enzymes involved in antioxidant defense, protein regulation, and prevention of aging-associated diseases. Biochim Biophys Acta. 2005; 1703:213-219. [PubMed: 15680229]

Moskovitz J. Prolonged selenium-deficient diet in MsrA knockout mice causes enhanced oxidative modification to proteins and affects the levels of antioxidant enzymes in a tissue-specific manner. Free Radic Res. 2007; 41:162-171. [PubMed: 17364942]

Moskovitz J, Bar-Noy S, Williams WM, Requena J, Berlett BS, Stadtman ER. Methionine sulfoxide reductase (MsrA) is a regulator of antioxidant defense and lifespan in mammals. Proc Natl Acad Sci U S A. 2001; 98:12920-12925. [PubMed: 11606777]

Nachshen DA, Sanchez-Armass S. Co-operative action of calcium ions in dopamine release from rat brain synaptosomes. J Physiol. 1987; 387:415-423. [PubMed: 3656180]

Neves G, Lagnado L. The kinetics of exocytosis and endocytosis in the synaptic terminal of goldfish retinal bipolar cells. J Physiol. 1999; 515(Pt 1):181-202. [PubMed: 9925888]

Oien D, Wang X, Moskovitz J. Genomic and Proteomic Analyses of the Methionine Sulfoxide Reductase A Knockout Mouse. Current Proteomics. 2008a; 5:96-103.

Oien DB, Moskovitz J. Substrates of the methionine sulfoxide reductase system and their physiological relevance. Curr Top Dev Biol. 2008; 80:93-133. [PubMed: 17950373]

Oien DB, Ortiz AN, Rittel AG, Dobrowsky RT, Johnson MA, Levant B, Fowler SC, Moskovitz J. Dopamine D2 Receptor Function is Compromised in the Brain of the Methionine Sulfoxide Reductase A Knockout Mouse. J Neurochem. 2010; 114(1):51-61. [PubMed: 20374422]

Oien DB, Osterhaus GL, Latif SA, Pinkston JW, Fulks J, Johnson M, Fowler SC, Moskovitz J. MsrA knockout mouse exhibits abnormal behavior and brain dopamine levels. Free Rad Biol Med. 2008b; 45:193-200. [PubMed: 18466776]

Oien DB, Osterhaus GL, Lundquist BL, Fowler SC, Moskovitz J. Caloric restriction alleviates abnormal locomotor activity and dopamine levels in the brain of the methionine sulfoxide reductase A knockout mouse. Neurosci Lett. 2010; 468:38-41. [PubMed: 19854239] 
Oien DB, Shinogle HE, Moore DS, Moskovitz J. Clearance and phosphorylation of alpha-synuclein are inhibited in methionine sulfoxide reductase a null yeast cells. J Mol Neurosci. 2009; 39:323 332. [PubMed: 19653131]

Ortiz AN, Kurth BJ, Osterhaus GL, Johnson MA. Dysregulation of intracellular dopamine stores revealed in the R6/2 mouse striatum. J Neurochem. 2010; 112:755-761. [PubMed: 19929911]

Outeiro TF, Klucken J, Bercury K, Tetzlaff J, Putcha P, Oliveira LM, Quintas A, McLean PJ, Hyman BT. Dopamine-induced conformational changes in alpha-synuclein. PLoS One. 2009; 4:e6906. [PubMed: 19730729]

Pal R, Oien DB, Ersen FY, Moskovitz J. Elevated levels of brain-pathologies associated with neurodegenerative diseases in the methionine sulfoxide reductase A knockout mouse. Exp Brain Res. 2007; 180:765-774. [PubMed: 17333008]

Palacios J, Sepulveda MR, Lee AG, Mata AM. Ca2+ transport by the synaptosomal plasma membrane Ca2+-ATPase and the effect of thioridazine. Biochemistry. 2004; 43:2353-2358. [PubMed: 14979732]

Patten DA, Germain M, Kelly MA, Slack RS. Reactive oxygen species: stuck in the middle of neurodegeneration. J Alzheimers Dis. 20(Suppl 2):S357-S367. [PubMed: 20421690]

Perez-Severiano F, Santamaria A, Pedraza-Chaverri J, Medina-Campos ON, Rios C, Segovia J. Increased formation of reactive oxygen species, but no changes in glutathione peroxidase activity, in striata of mice transgenic for the Huntington's disease mutation. Neurochem Res. 2004; 29:729733. [PubMed: 15098934]

Rizzoli SO, Betz WJ. Synaptic vesicle pools. Nat Rev Neurosci. 2005; 6:57-69. [PubMed: 15611727]

Rose SD, Lejen T, Casaletti L, Larson RE, Pene TD, Trifaro JM. Molecular motors involved in chromaffin cell secretion. Ann N Y Acad Sci. 2002; 971:222-231. [PubMed: 12438122]

Venton BJ, Seipel AT, Phillips PE, Wetsel WC, Gitler D, Greengard P, Augustine GJ, Wightman RM. Cocaine increases dopamine release by mobilization of a synapsin-dependent reserve pool. $\mathrm{J}$ Neurosci. 2006; 26:3206-3209. [PubMed: 16554471]

Yavich L, Oksman M, Tanila H, Kerokoski P, Hiltunen M, van Groen T, Puolivali J, Mannisto PT, Garcia-Horsman A, MacDonald E, Beyreuther K, Hartmann T, Jakala P. Locomotor activity and evoked dopamine release are reduced in mice overexpressing A30P-mutated human alphasynuclein. Neurobiol Dis. 2005; 20:303-313. [PubMed: 16242637]

Yavich L, Tanila H, Vepsalainen S, Jakala P. Role of alpha-synuclein in presynaptic dopamine recruitment. J Neurosci. 2004; 24:11165-11170. [PubMed: 15590933]

Zucker RS and Regehr WG. Short-term synaptic plasticity. Annu Rev Physiol. 2002; 64:355-405. [PubMed: 11826273] 


\section{Research Highlights}

$>\quad$ Dopamine reserve pools were quantified in $\mathrm{MsrA}^{-1-}$ mice and WT control mice

$>\quad \mathrm{MsrA}^{-1-}$ mice had an enhanced dopamine reserve pool compared to WT mice.

$>\quad$ Reserve pool mobilization occurred over a longer time period in $\mathrm{MsrA}^{-/-}$ mice.

$>\quad$ Dopamine release was equally sensitive to extracellular $\mathrm{Ca}^{2+}$ in $\mathrm{MsrA}^{-/-}$and WT mice.

$>\quad$ Study among first to measure reserve pool dopamine in an oxidative stress model. 
A

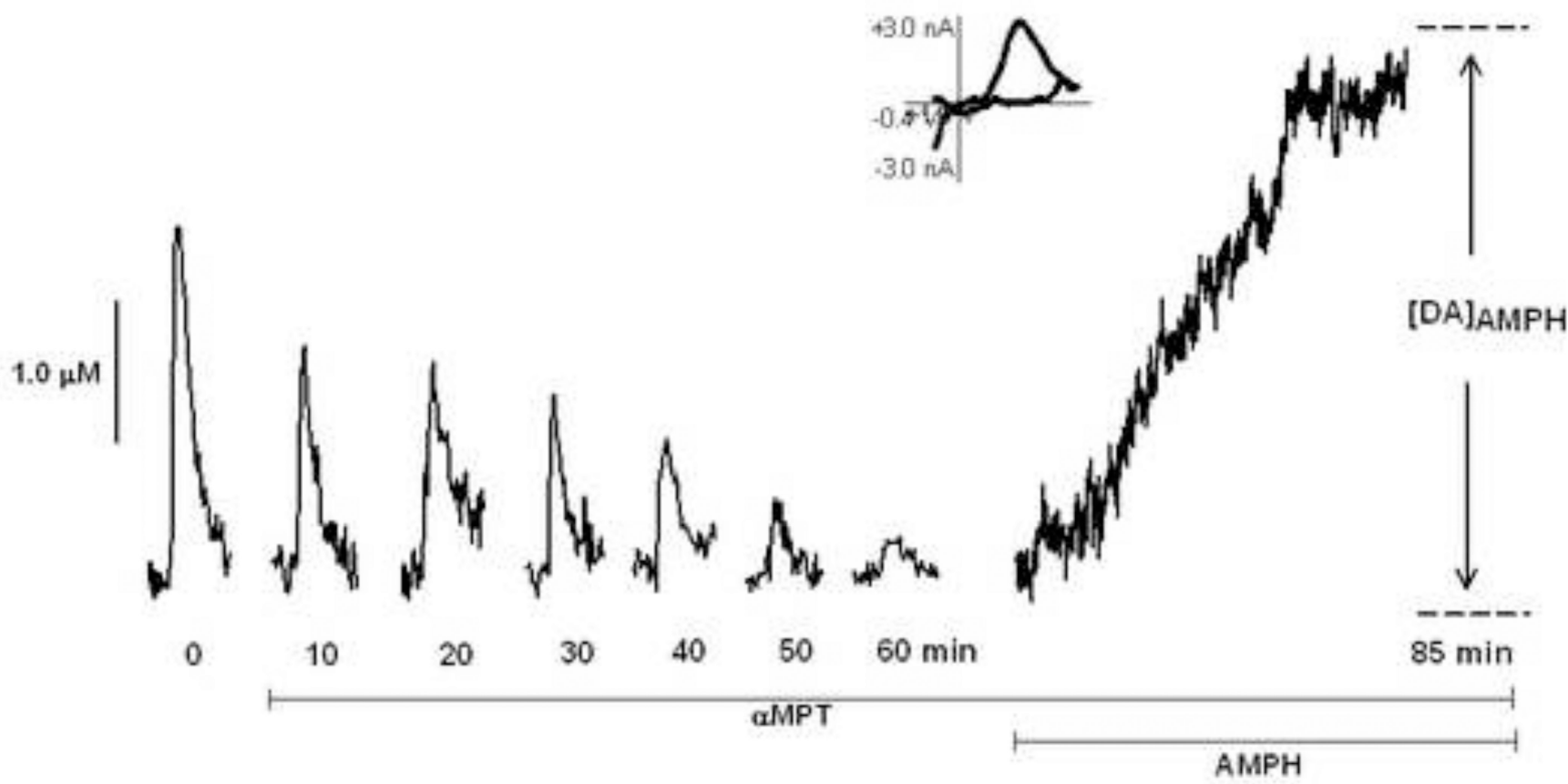

B

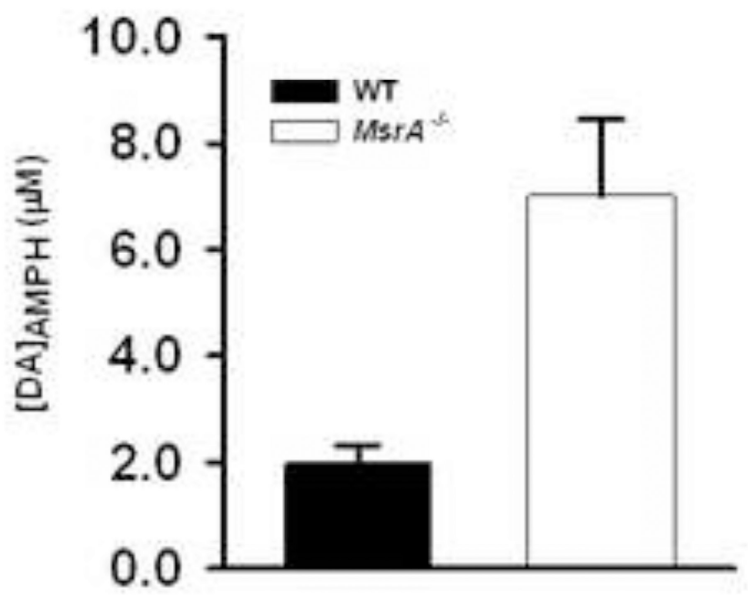

Figure 1. AMPH induced DA efflux is increased in $\mathrm{MsrA}^{-/-}$mice compared to WT mice (A) Representative data in which a brain slice from a WT mouse was treated with $50 \mu \mathrm{M}$ aMPT while single stimulus pulses were applied every 5 min until DA release was diminished. The slice was then treated with $20 \mu \mathrm{M}$ AMPH for $25 \mathrm{~min}$, and DA] $]_{\mathrm{AMPH}}$ was measured. A CV is provided from the time of peak release, and confirms the release of DA.

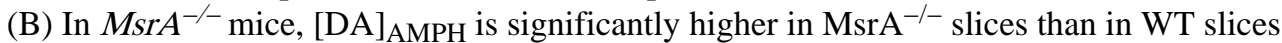
$\left(* p<0.05 ; \mathrm{MsrA}^{-/}, 7.02 \pm 1.42 \mu \mathrm{M}, \mathrm{n}=5\right.$ mice; WT, $\left.5.63 \pm 0.33 \mu \mathrm{M}, \mathrm{n}=4\right)$. 
A

WT

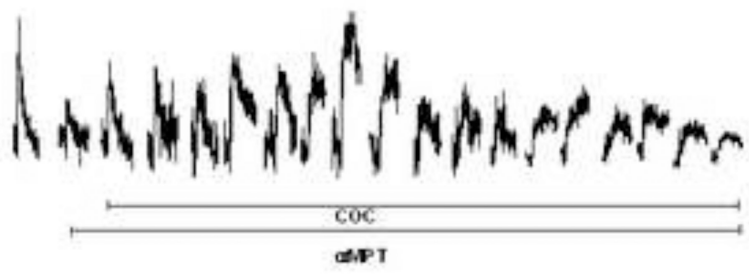

$1.0 \mu \mathrm{M}$

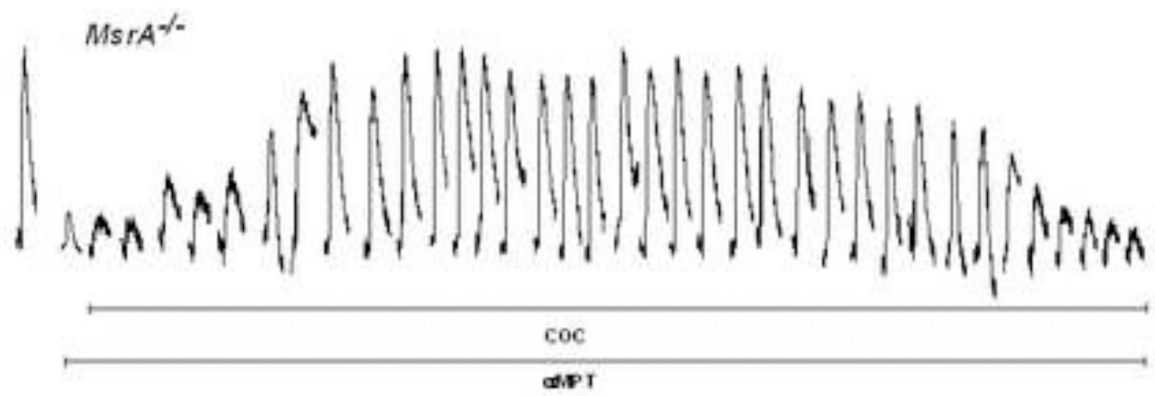

B

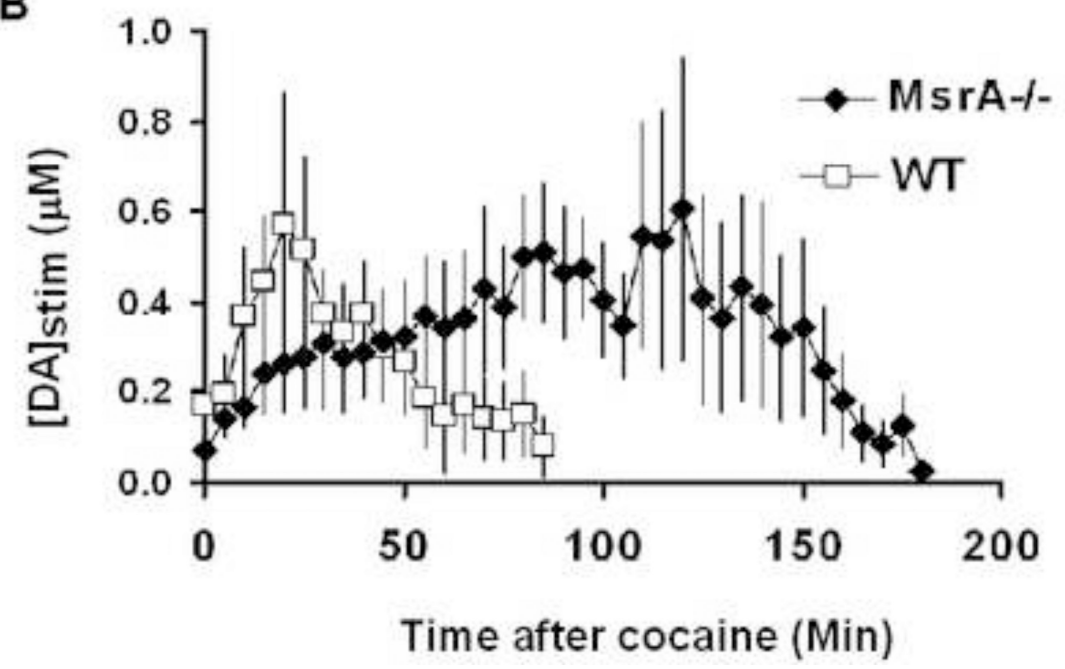

Figure 2. More reserve pool DA is mobilized in slices from $\mathrm{MsrA}^{-/-}$mice compared to those from WT mice

Brain slices from $\mathrm{Msr}^{-/-}$and WT mice were exposed to $50 \mu \mathrm{M}$ aMPT while single stimulus pulses were applied every $5 \mathrm{~min}$. Once DA release disappeared, $20 \mu \mathrm{M} \mathrm{COC}$ was added to the slice. The application of stimulus pulses was continued during this time. (A) Representative data from $\mathrm{MsrA}^{-/}$and WT slices. The addition of COC after pretreatment with aMPT resulted in an increase in stimulated DA release. Stimulated release plots taken immediately after the addition of aMPT have been omitted for clarity. (B) Pooled data from $M s r A^{-/-}$and WT mice after the addition of COC. Each data point represents the average value $( \pm \mathrm{SEM})$ of $[\mathrm{DA}]_{\text {stim }}$ obtained from $5 \mathrm{Msr}^{-/-}$mice and $6 \mathrm{WT}$ mice. 
A

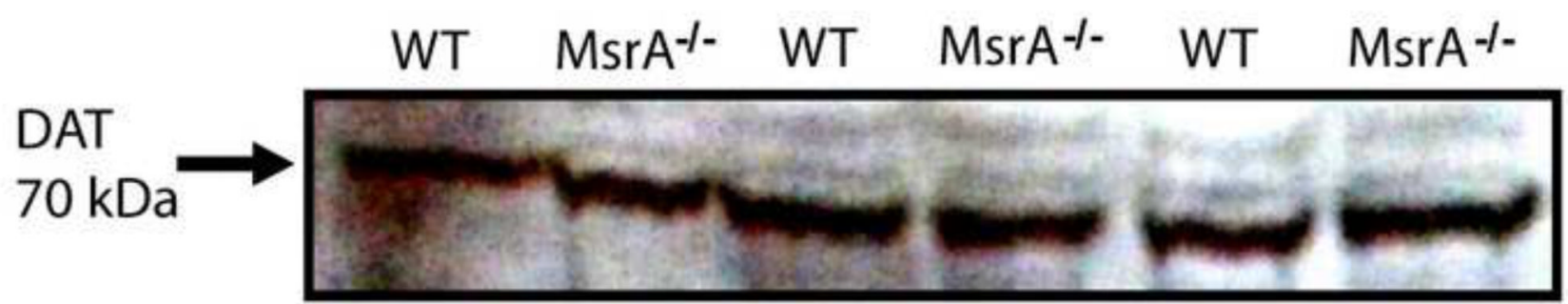

B

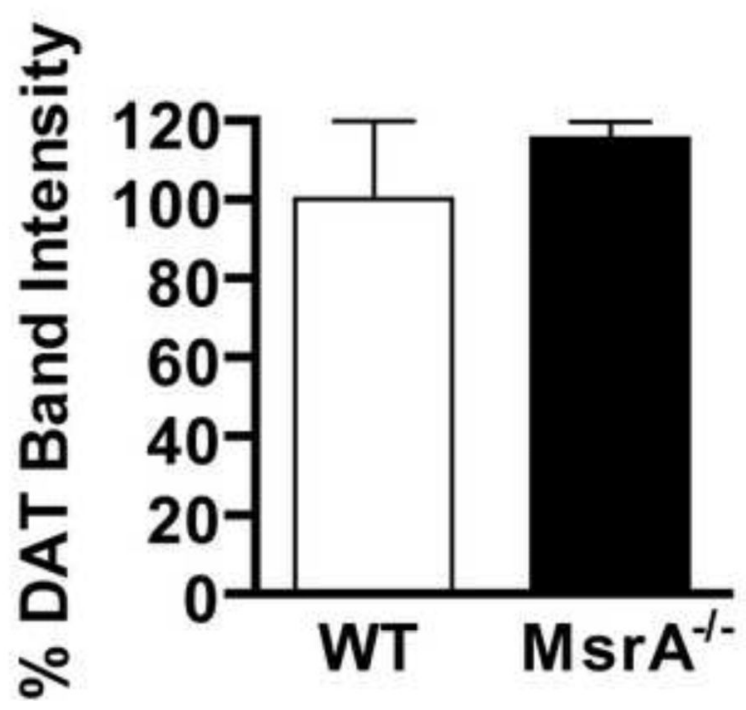

Figure 3. DAT protein levels are unchanged in $\mathrm{MsrA}^{-/-}$mice

$M s r A^{-1-}$ and WT cerebral membrane fractions were solubilized and equal amounts of protein were separated by gel electrophoresis followed by western blot analysis. (A) Protein bands detected by anti-DAT antibodies indicate similar amounts of the protein at about 70 $\mathrm{kDa}$. (B) Densitometry values of DAT protein bands are shown as an average density from $M_{s r} A^{-/}$(black) and WT (white) bands ( $p=0.69 ; \mathrm{n}=3 \mathrm{MsrA}^{-/-}$and 3 WT mice). 


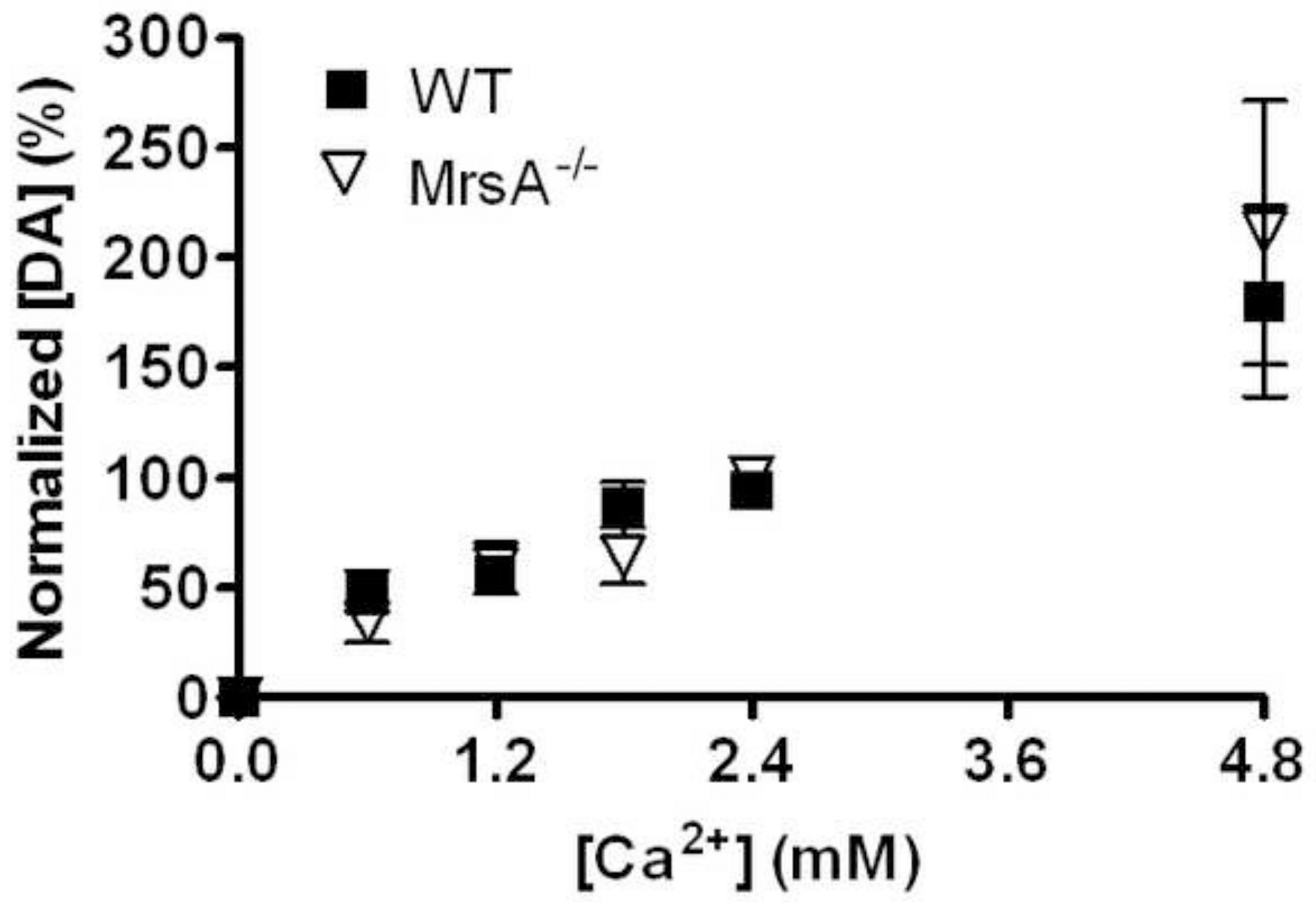

Figure 4. Calcium-dependent release was unchanged in 12-month-old $\mathrm{Msr}^{-/-}$mice compared to age-matched WT mice

Brain slices were treated with $0,0.6,1.8$, and $2.4 \mathrm{mM}$ concentrations of extracellular calcium and electrically stimulated DA release was measured for $15 \mathrm{~min}$ at each concentration. DA release was normalized to maximum DA release within each data set. At $0 \mathrm{mM}$ calcium no DA release was detected. Two-way ANOVA did not reveal an overall genotype effect on DA release throughout the entire range of extracellular calcium concentrations (Fig. $4 ; p=0.51 ; \mathrm{F}_{1,21}=0.48 ; \mathrm{MsrA}^{-/-}, \mathrm{n}=4$ mice; WT, $\mathrm{n}=6$ mice). 